\title{
AKT inhibits the phosphorylation level of H2A at Tyr57 via CK2 $\alpha$ to promote the progression of gastric cancer
}

\author{
Zhi-Da Chen $^{1 \#}$, Peng-Fei Zhang ${ }^{2 *}$, Hong-Qing Xi ${ }^{1}$, Bo Wei ${ }^{1}$, Lin Chen ${ }^{1}$ \\ ${ }^{1}$ Department of General Surgery, First Medical Center of Chinese PLA General Hospital, Beijing, China; ${ }^{2}$ Department of Oncology, First Medical \\ Center of Chinese PLA General Hospital, Beijing, China \\ Contributions: (I) Conception and design: ZD Chen, PF Zhang; (II) Administrative support: B Wei, L Chen; (III) Provision of study materials or \\ patients: B Wei, L Chen; (IV) Collection and assembly of data: HQ Xi; (V) Data analysis and interpretation: ZD Chen, PF Zhang; (VI) Manuscript \\ writing: All authors; (VII) Final approval of manuscript: All authors. \\ \#These authors contributed equally to this work. \\ Correspondence to: Lin Chen; Bo Wei. Department of General Surgery, First Medical Center of Chinese PLA General Hospital, 28, Fuxing Road, \\ Haidian District, Beijing 100853, China. Email: chenlinbj@sina.com; weibo@vip.163.com.
}

\begin{abstract}
Background: Histone H2A and its variants have an important effect on DNA damage repair and cancer development. Protein kinase B (AKT) can regulate various cellular functions and play critical roles in the progression of different cancers. However, the interaction mechanism of H2A with AKT in gastric cancer (GC) has not been reported. A series of experiments were carried out in the present study to investigate this issue.

Methods: Firstly, we used western blot and immunoprecipitation assays to determine the correlation between AKT and H2A, then detected the relationship between AKT and protein kinase CK2 $\alpha$ that can phosphorylate $\mathrm{H} 2 \mathrm{~A}$ at $\mathrm{Tyr} 57$ site $\left(\mathrm{H} 2 \mathrm{~A}^{\mathrm{Y} 57}\right)$, and next examined the interaction among AKT, CK2 $\alpha$, and $\mathrm{H} 2 \mathrm{~A}$ in SNU-16 cells. Subsequently, the effect of these molecules on the cellular proliferation, migration, and invasion was measured by Cell Counting Kit-8 (CCK-8), wound healing, and transwell invasion assays.

Results: Our study preliminarily found that AKT was negatively correlated with H2A phosphorylation at the Tyr 57 site $\left(\mathrm{H} 2 \mathrm{~A}^{\mathrm{Y} 57 \mathrm{p}}\right)$. It was revealed that AKT mediated the phosphorylation of CK2 $\alpha$ at the T13 site, which decreased the affinity of CK2 $\alpha$ with its substrate histone H2A and inhibited the level of $\mathrm{H} 2 \mathrm{~A}^{\mathrm{Y} 57 \mathrm{p}}$ in GC cells. Furthermore, AKT-mediated CK2 $\alpha$ phosphorylation promoted the proliferation, migration, and invasion of SNU-16 cells possibly through downregulating $\mathrm{H}_{2} \mathrm{~A}^{\mathrm{Y} 57 \mathrm{p}}$ level.
\end{abstract}

Conclusions: These findings contribute to understanding the interactions among AKT, CK2 $\alpha$, and $\mathrm{H} 2 \mathrm{~A}$ in GC, and provide the potential biomarkers for the diagnosis and treatment of GC.

Keywords: H2A; CK2 $\alpha$; AKT; gastric cancer (GC)

Submitted Apr 22, 2021. Accepted for publication Jul 22, 2021.

doi: 10.21037/jgo-21-260

View this article at: https://dx.doi.org/10.21037/jgo-21-260

\section{Introduction}

Gastric cancer (GC) is 1 of the 5 most common cancers in the world and has also been shown to be the second leading cause of death by cancer $(1,2)$. Although the treatment of cancer has improved, the main treatment approach is surgery with chemotherapy, which cannot effectively improve the prognosis and survival rate of patients with $\operatorname{GC}(3,4)$. A reason for this is the rapid development of GC and lack of specific clinical symptoms, which makes early diagnosis difficult; another is the high probability of recurrence and metastasis of GC after surgery and due to drug resistance $(5,6)$. Therefore, it is urgent to study the pathogenesis of GC and find new biomarkers for GC treatment.

Epigenetics refers to the study of change in genetic expression that does not alter the DNA sequence but can be inherited $(7,8)$. Post-translational histone modifications are 1 of the most important research directions of epigenetics, which include methylation, ubiquitination, acetylation, and 
phosphorylation (9). Histone modifications are implicated in gene expression and play critical roles in regulating cell cycle, DNA replication, and transcription (10). For instance, phosphorylation of histone $\mathrm{H} 2 \mathrm{~A}$ is associated with many biological processes, including DNA-double-strand-break repair $(11,12)$. Phosphorylation of H2A at Ser121 has been found to prevent chromosome instability (13). The site H2A at $\operatorname{Tyr} 57\left(\mathrm{H} 2 \mathrm{~A}^{\mathrm{Y} 57}\right)$ is a new conserved phosphorylation site in $\mathrm{H} 2 \mathrm{~A}$, and its phosphorylation $\left(\mathrm{H} 2 \mathrm{~A}^{\mathrm{Y} 57 \mathrm{p}}\right)$ is mediated by CK2 $\alpha$, which can regulate transcriptional elongation (14). Although histone $\mathrm{H} 2 \mathrm{~A}$ has been widely reported, a functional understanding of $\mathrm{H} 2 \mathrm{~A}^{\mathrm{Y} 57 \mathrm{p}}$ is still lacking. Many reports have suggested that AKT is closely associated with histone modifications such as acetylation, methylation, and phosphorylation to mediate the progression of cancers (15-17). Park et al. indicated that AKT decreases apoptosis by phosphorylation of $\mathrm{H} 2 \mathrm{~A}$ at threonine- 17 under oxidative stress conditions in neurons and PC12 cells (18). However, AKT mediated phosphorylation of $\mathrm{H} 2 \mathrm{~A}$ at Tyr57 has not been reported, and the relationship between histone H2A phosphorylation at Tyr57 and cancer has rarely been studied. Since AKT and histone H2A are crucial for the development of GC (19-21), we aimed to study the relationship between AKT and the phosphorylation of $\mathrm{H} 2 \mathrm{~A}$ at Tyr57 to explore the specific molecular mechanism of the AKT/H2A pathway affecting GC, so as to expose new ideas for the prevention and treatment of GC. We present the following article in accordance with the MDAR reporting checklist (available at https://dx.doi.org/10.21037/jgo-21-260).

\section{Methods}

\section{Cell culture}

Human GC cell lines KATO III, HGC-27, and NCI-N87 were purchased from Nanjing Cobioer Gene Technology Co., Ltd. (Nanjing, China). The SNU-5 and SNU-16 cells were obtained from the American Type Culture Collection (ATCC, Rockville, MD, USA). The MKN-28, MKN-74 cells were purchased from Mingzhou Biotechnology Co., Ltd. (Ningbo, Zhejiang, China). The KATO III and SNU-5 cells were grown in Iscove's Modified Dulbecco's Medium (IMDM) with 10\% fetal bovine serum (FBS) (Gibco, Waltham, MA, USA), 1\% penicillin-streptomycin (Sangon Biotech, Shanghai, China). Other cell lines were grown in Roswell Park Memorial Institute (RPMI) 1640 medium (Gibco, Waltham, MA, USA) with $10 \% \mathrm{FBS}, 0.1 \mathrm{mg} / \mathrm{mL}$ penicillinstreptomycin. All cells were cultured in a humidified incubator at $37^{\circ} \mathrm{C}$ with $5 \% \mathrm{CO}_{2}$ and $95 \%$ humidity.

\section{Western blot}

The cells were lysed using lysis buffer $(0.5 \%$ sodium deoxycholate, $50 \mathrm{mM}$ Tris, $\mathrm{pH} 7.4,150 \mathrm{mM} \mathrm{NaCl}, 1 \%$ NP-40) with $20 \mathrm{mg} / \mathrm{L}$ DNase on ice for $30 \mathrm{~min}$, and the protein concentration of cell lysates was measured by the bicinchoninic acid (BCA) method. The BCA working solution (A solution: B solution $=50: 1$ ) was prepared and set for $24 \mathrm{~h}$. A total of $0.5 \mathrm{mg} / \mathrm{mL}$ standard protein and the sample protein were diluted and added into a 96-well plate with $20 \mu \mathrm{L} /$ well, BCA working fluid was added with $200 \mu \mathrm{L} /$ well, and the absorbance [optical density $(\mathrm{OD})=562$ ] was measured after $30 \mathrm{~min}$ staining at $37^{\circ} \mathrm{C}$. Finally, the concentration of sample protein was calculated according to the standard curve. The protein samples were added onto $10 \%$ sodium dodecyl sulfate polyacrylamide gel electrophoresis (SDS-PAGE) gel equally for electrophoresis and then transferred onto polyvinylidene fluoride (PVDF) membranes. The membranes were blocked with $5 \%$ non-fat milk for $1 \mathrm{~h}$ and incubated overnight at $4{ }^{\circ} \mathrm{C}$ with primary antibodies against: p-CK2 $\alpha$ (ab137580, Abcam), H2A (\#2578), AKT (\#9272), CK2 $\alpha$ (\#2656), p-AKT (\#4058), P-GSK3ß (\#5558S), T-GSK3ß (\#5676), HA-tag (\#3724), and Myc-tag (\#2272, Cell Signaling Technology, Danvers, MA, USA). In addition, the antibody of $\mathrm{H} 2 \mathrm{~A}^{\mathrm{Y} 57 \mathrm{p}}$ was prepared by Biomatik (Kitchener, Ontario, Canada) using the peptide of $\mathrm{H}_{2} \mathrm{~A}^{\mathrm{Y} 57 \mathrm{p}}$ (LE (pY) LTAEILELAGNC) as antigen. The membranes were washed with tris buffered saline with Tween 20 (TBST) buffer (to move the unbound proteins), and incubated with the secondary antibodies Goat Anti-Rabbit IgG H\&L (HRP) (ab6721) for $1 \mathrm{~h}$ at room temperature. The isoform $\beta$-actin was used as an internal control. Each experiment was performed in triplicate.

\section{Co-immunoprecipitation (CoIP)}

The cells were flushed with phosphate buffered saline (PBS) and lysed in an ice-cold buffer ( $\mathrm{pH} 7.4,1 \%$ Triton $\mathrm{X}-100,40 \mathrm{Mm}$ Hepes, $0.1 \%$ SDS, $100 \mathrm{mM} \mathrm{NaCl}, 0.5 \%$ Na-deoxycholate, $25 \mathrm{mM} \beta$-glycerophosphate, $1 \mathrm{mM}$ ethylenediamine tetraacetic acid (EDTA), $10 \mu \mathrm{g} / \mathrm{mL}$ leupeptin and aprotinin, and $1 \mathrm{mM} \mathrm{Na-orthovanadate)}$. The lysates were washed by centrifugation at 25,000 $\times \mathrm{g}$ for $20 \mathrm{~min}$, and incubated with antibodies against MycCK $2 \alpha$, hemagglutinin (HA)-AKT, CK2 $\alpha$, AKT, and $\mathrm{H} 2 \mathrm{~A}$, separately, for $30 \mathrm{~min}$ at $4^{\circ} \mathrm{C}$. Then, the protein A-sepharose bead slurry was added into the lysates and rotation incubated for another $3 \mathrm{~h}$. The immunoprecipitates were rinsed 3 times in ice-cold PBS and added to an SDSPAGE sample buffer to be boiled for $5 \mathrm{~min}$, followed by 
the performance of western blot. The results represented 3 independent experiments.

\section{Cell fractionation experiments}

In order to fractionate the cellular proteins into cytoplasmic protein, soluble nucleocytoplasmic proteins and insoluble nucleocytoplasmic proteins (chromatin-binding proteins), SNU-16 cells were resuspended in $400 \mu \mathrm{L}$ lysis buffer A (Hepes pH 7.910 mM, EGTG 0.1 mM, KCl 10 mM, $\mathrm{MgCl}_{2}$ $1.5 \mathrm{mM}$, EDTA $0.1 \mathrm{mM}$, and NP-40 $0.1 \%$ ) and incubated in a shaker incubator for $15 \mathrm{~min}$ at $4{ }^{\circ} \mathrm{C}$. The supernatant (cytoplasm) obtained by centrifugation was discarded, while the sediments were suspended in $125 \mu \mathrm{L}$ lysis buffer B [Hepes pH $7.920 \mathrm{mM}, \mathrm{MgCl}_{2} 1.5 \mathrm{mM}, \mathrm{NaCl} 150 \mathrm{mM}$, Glyserol $10 \%$, egtazic acid (EGTA) $0.25 \mathrm{mM}$ ] and incubated in a shaker incubator for $20 \mathrm{~min}$ at $4{ }^{\circ} \mathrm{C}$. The supernatant was collected as nuclear soluble fraction. Then, the precipitates were resuspended in $250 \mu \mathrm{L}$ buffer (Tris- $\mathrm{HCl} \mathrm{pH} 7.5$ $50 \mathrm{mM}$, NP-40 1\%, SDS 0.1\%, DOC 0.5\%, $150 \mathrm{mM} \mathrm{NaCl}$ ) and treated with ultrasonication and centrifugation, and the supernatant was insoluble nuclear fraction. The SNU-16 cells in each state were subjected to 3 independent experiments. Finally, the nuclear soluble fraction and the insoluble nuclear fraction (chromatin) were used to implement western blot to explore the affinity between CK2 $\alpha$ and $\mathrm{H} 2 \mathrm{~A}$.

\section{Cell transfection and treatment}

We constructed the plasmids of DN-AKT, constitutively activated-AKT $(\mathrm{CA}-\mathrm{AKT}), \mathrm{CK} 2 \alpha^{\mathrm{T} 13 \mathrm{~A}}, \mathrm{CK} 2 \alpha^{\mathrm{T} 13 \mathrm{E}}$, and siAKT/siCK $2 \alpha$ using pEGFP-N1 vector (Sangon Biotech, Shanghai, China). Small interfering RNA (SiRNA) duplexes against AKT, CK2 $\alpha$, and negative control siRNA were purchased from GenePharm Co. Ltd. (Shanghai, China). The cells were cultured overnight in 6-well plates until they were $70-90 \%$ confluent, and the cell transfection was implemented according the instructions of Lipofectamine ${ }^{\mathrm{TM}}$ LTX Reagent with PLUS ${ }^{\mathrm{TM}}$ Reagent (15338030, ThermoFisher, Waltham, MA, USA). The treatment conditions of GC cells when they needed to be treated with hormones were $15 \mathrm{ng} / \mathrm{mL}$ of insulin-like growth factor (IGF) for $30 \mathrm{~min}$, or $16 \mu \mathrm{M}$ of LY294002 for $24 \mathrm{~h}$. The results represented 3 independent experiments.

\section{In vitro kinase activity assay}

At a density of $0.2 \times 10^{6}$ cells $/ \mathrm{mL}, \mathrm{SNU}-16$ cells were transfected with HA-tagged CA-AKT $(10 \mu \mathrm{g})$. After transfection for $48 \mathrm{~h}$, HA-AKT was immunoprecipitated from the cell lysates, followed by incubation with purified wild-type (WT) or mutant CK2 $\alpha$ and kinase reaction mixture with $5 \mu \mathrm{Ci}$ of $\left[\gamma_{-}{ }^{32} \mathrm{P}\right]$ ATP and $50 \mathrm{mM}$ cold ATP in kinase buffer at $37^{\circ} \mathrm{C}$ for $30 \mathrm{~min}$. Reaction was terminated by adding $4 \times$ SDS sample loading buffer $(10 \mu \mathrm{L})$, and the samples were denatured at $95{ }^{\circ} \mathrm{C}$ for $5 \mathrm{~min}$. The samples were then analyzed by western blot. The image of ${ }^{32} \mathrm{p}$-labeled proteins was captured by autoradiography. The above same procedures were performed to detect the reaction between WT-, T13A, or T13E-CK2 $\alpha$ and H2A. The results represented 3 independent experiments.

\section{Cell proliferation assay}

Cell proliferation was measured by Cell Counting Kit8 (CCK-8) assay. After transfection, SNU-16 cells were collected and inoculated in a 96-well plate $\left(1 \times 10^{4}\right.$ cells per well), followed by incubation in RPMI 1640 medium with $10 \% \mathrm{FBS}$ at $37^{\circ} \mathrm{C}, 5 \% \mathrm{CO}_{2}$ for $24,48,72$, and $96 \mathrm{~h}$. At the corresponding time point, $10 \mu \mathrm{L}$ of CCK-8 solution was added to each well of the plate and then incubated for another $4 \mathrm{~h}$ in the incubator. The absorbance was measured at $450 \mathrm{~nm}$ using a microplate reader. The experiment was repeated 3 times.

\section{Wound healing assay}

Cell migration was measured using a wound healing assay. After transfection, SNU-16 cells were cultured in 6-well plates to $100 \%$ confluence, and then the cell monolayer was scratched using a sterile $100 \mu \mathrm{L}$ pipette tip in a straight line. Next, the cells were washed with PBS and incubated in RPMI 1640 medium without serum for $24 \mathrm{~h}$ at $37^{\circ} \mathrm{C}$, $5 \% \mathrm{CO}_{2}$. The images of the cells were visualized using a light microscope (Olympus BX51, Olympus Corporation, Tokyo, Japan; magnification, $\times 100)$. The results represented 3 independent experiments.

\section{Transwell invasion assay}

Cell invasion was analyzed by transwell chamber. The cells were digested by pancreatin and resuspended in serum-free RPMI 1640 medium. After the lower compartment was filled with complete medium, the $4 \times 10^{4}$ cells were added into the upper compartment of a transwell chamber ( $8 \mu \mathrm{m}$ pore; BD Biosciences, Becton, Dickinson and Company, San Jose, CA, USA) pre-coated with Matrigel and cultured for $24 \mathrm{~h}$ at $37^{\circ} \mathrm{C}$. Then, the cells on the top surface of the chamber were wiped off with a cotton swab, the cells that invaded the lower side of the chamber were fixed with $5 \%$ glutaraldehyde for $15 \mathrm{~min}$ and stained with crystal violet for $10 \mathrm{~min}$. Finally, the cells were 
counted under light microscope (Olympus BX51, Olympus Corporation, magnification, $\times 200$ ). The results represented 3 independent experiments.

\section{Analysis of apoptosis}

SUN-16 cells that cultured in the 6-well plates were washed with PBS and digested by trypsin. After the digestion was stopped, the cells were washed with PBS, and the cells were collected by centrifuging at $200 \times \mathrm{g}$ for $5 \mathrm{~min}$. Next, Annexin V-FITC binding solution was used to resuspend the cells, and the cells were incubated at room temperature and dark for $10 \mathrm{~min}$, and then the cells were collected by centrifuging at $200 \times \mathrm{g}$ for $5 \mathrm{~min}$. The cells were then resuspend with Annexin V-FITC binding solution and co-cultured with the propidium iodide (PI) on ice and dark for $10 \mathrm{~min}$. Finally, cells were determined for early and late apoptosis by using a BD FACSCalibur flow cytometer (Bedford, MA) and the data were analyzed by GraphPad Prism 7.0.

\section{Statistical analysis}

Data were presented as the mean \pm standard error of the mean (SEM), and each experiment was repeated in triplicate. The software GraphPad Prism 7.0 (San Diego, CA, USA) was used to analyze the data. We performed statistical analysis according to analysis of variance (ANOVA) followed by Sidak's multiple comparisons test when datasets contained multiple groups, and the comparison between the 2 groups was statistically analyzed according to $t$-test. A P value $<0.05$ was considered statistically significant.

\section{Results}

\section{AKT inversely regulates $\mathrm{H} 2 A^{Y 57 p}$}

Western blot assay was performed to verify the relationship between p-AKT and $\mathrm{H}_{2} \mathrm{~A}^{\mathrm{Y} 57 \mathrm{p}}$. We discovered that GC cells with lower levels of $\mathrm{H} 2 \mathrm{~A}^{\mathrm{Y} 57 \mathrm{p}}$ usually had high levels of p-AKT (Figure 1A). Thus, the expression levels of $\mathrm{H} 2 \mathrm{~A}^{\mathrm{Y} 57 \mathrm{p}}$ were negatively correlated with p-AKT levels. This negative correlation prompted us to detect whether alteration of AKT activity can change the expression of $\mathrm{H} 2 \mathrm{~A}^{\mathrm{Y} 57 \mathrm{p}}$. It was shown that IGF as an activator of AKT could increase the level of p-AKT but inhibit the level of $\mathrm{H} 2 \mathrm{~A}^{\mathrm{Y} 57 \mathrm{p}}$, while the addition of the PI3K-AKT inhibitor, LY294002, could reverse this effect (Figure 1B). Similarly, the level of $\mathrm{H} 2 \mathrm{~A}^{\mathrm{Y} 57 \mathrm{p}}$ was increased in cells transfected by dominant negative AKT (DN-AKT) or AKT siRNA (Figure 1C,1D). Additionally, the correlation between AKT activity and the level of $\mathrm{H}_{2} \mathrm{~A}^{\mathrm{Y} 57 \mathrm{p}}$ was further verified by changing the treatment duration of LY294002. The results showed that the level of $\mathrm{H} 2 \mathrm{~A}^{\mathrm{Y} 57 \mathrm{p}}$ displayed an increasing trend over time, while the level of p-AKT had the opposite trend (Figure 1E). In conclusion, AKT could negatively regulate the phosphorylation level of $\mathrm{H} 2 \mathrm{~A}^{\mathrm{Y} 57}$.

\section{AKT phosphorylates CK2a on T13 site}

To further explore the molecular mechanism, we attempted to study the relationship between AKT and CK2 $\alpha$ on account CK2 $\alpha$ having been shown to phosphorylate Tyr 57 in H2A $\left(\mathrm{H}_{2} \mathrm{~A}^{\mathrm{Y} 57}\right)$ (14). Firstly, CoIP experiments were performed to detect whether CK2 $\alpha$ is the target of AKT. The results showed that CK2 $\alpha$ is associated with CA-AKT but not DNAKT (Figure 2A). Furthermore, the association between endogenous AKT and CK2 $\alpha$ was also found, and this association was decreased in the cells treated with LY294002 (Figure 2B). Thus, these results suggested that CK2 $\alpha$ was the target of AKT and they could interact in GC cells.

Secondly, to determine whether AKT can phosphorylate CK2 $\alpha$, we applied the PhosphoSitePlus (https://www. phosphosite.org/homeAction.action) and Scansite (https:// scansite4.mit.edu/4.0/\#home) websites to find the AKT phosphorylation sites in CK2 $\alpha$, and obtained 1 potential site, T13. An in vitro kinase assay was performed to detect the interaction of HA-tagged AKT with WT CK $2 \alpha$ and mutants of CK2 $\alpha$ in which the phosphorylation site T13 was replaced by Ala or Glu (T13A and T13E) and glutathione S-transferase (GST). The results indicated that AKT could phosphorylate WT CK2 $\alpha$ but not CK2 $\alpha$ mutants (Figure 2C). To verify that AKT can indeed phosphorylate CK2 $\alpha$ at T13 site in vivo, we synthesized an antibody, which specifically recognized p-CK2 $\alpha$ at the T13 site but failed to detect an unphosphorylated CK2 $\alpha$ or an unrelated peptide (Figure S1). Thus, we speculated that AKT could phosphorylate CK2 $\alpha$ at T13 site.

Thirdly, to further verify the relationship between AKT and p-CK2 $\alpha$, the endogenous and exogenous CK2 $\alpha$ levels were determined by immunoprecipitation and western blot after SNU-16 cells had been treated with an AKT inhibitor (LY294002 or DN-AKT) or transfected with CK2 $\alpha$ plasmid. After SNU-16 cells were treated with LY294002 or DN-AKT, endogenous CK2 $\alpha$ was immunoprecipitated using a CK2 $\alpha$ antibody and subjected to western blot using a p-CK2 $\alpha$ antibody (Figure $2 D$ ). The p-CK2 $\alpha$ was observed in SNU-16 cells without LY294002 treatment, and it was not found in cells treated with LY294002 or transfected with DN-AKT (Figure 2D). When SNU-16 cells were immunoprecipitated with a p-CK2 $\alpha$ antibody, 


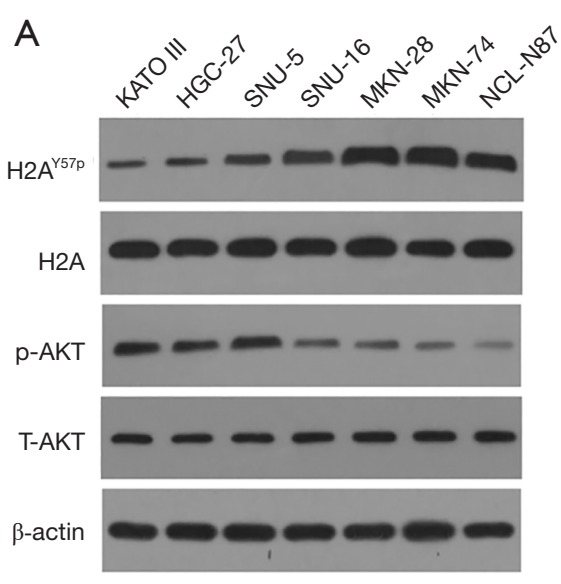

D

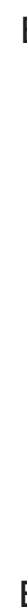

B
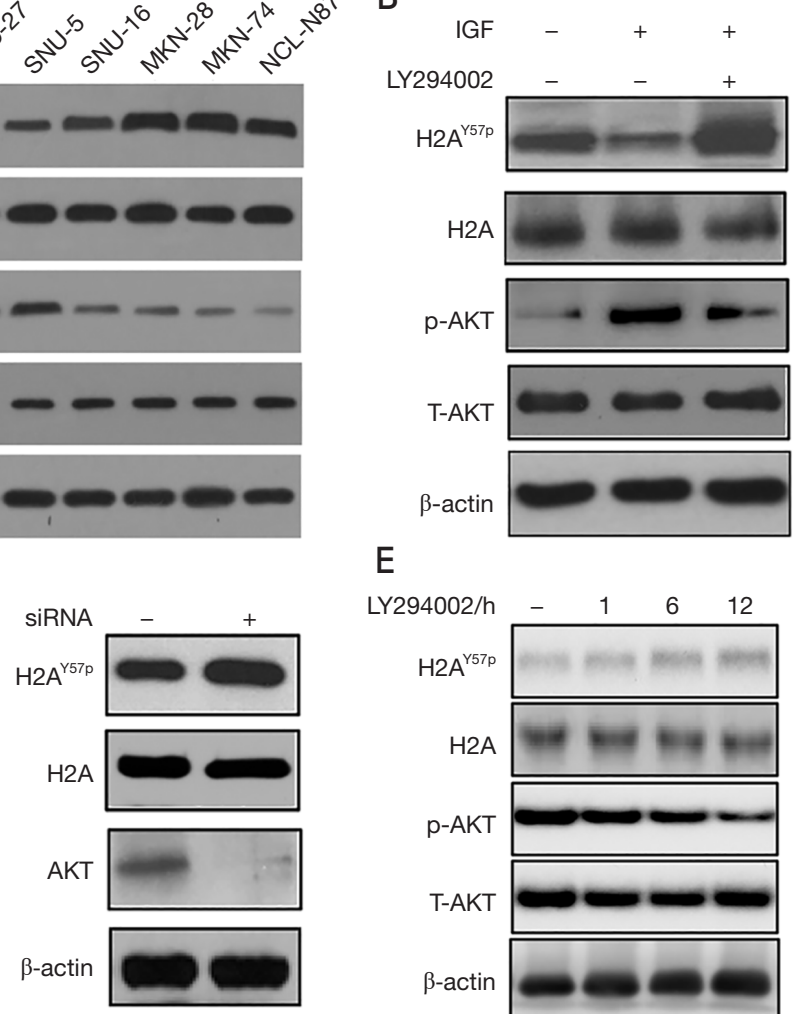

$\mathrm{LY} 294002 / \mathrm{h} \quad-\quad 1 \quad 6 \quad 12$

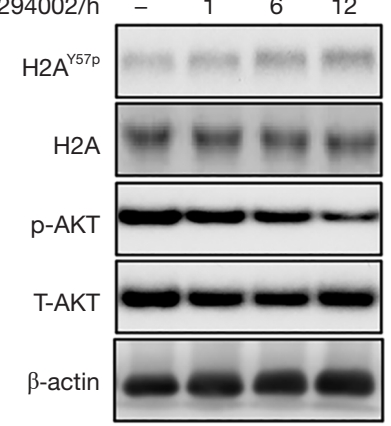

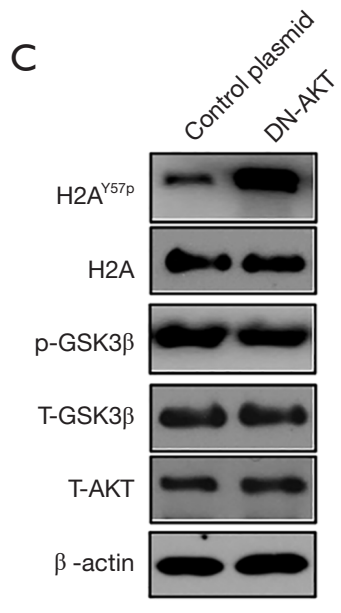

Figure $1 \mathrm{AKT}$ inversely regulates $\mathrm{H} 2 \mathrm{~A}^{\mathrm{Y} 57 \mathrm{p}}$. (A) $\mathrm{H} 2 \mathrm{~A}^{\mathrm{Y} 57 \mathrm{p}}$ and $\mathrm{p}-\mathrm{AKT}$ in different cell lines were assessed by western blot. (B) SNU-16 cells were treated with IGF and LY294002, and western blot was used to test the levels of H2 $\mathrm{A}^{\mathrm{Y} 57 \mathrm{p}}$ and p-AKT in the SNU-16 cell lines treated with the AKT inhibitor (LY294002) or an activator of AKT (IGF). (C) The level of H2A ${ }^{\mathrm{Y} 57 \mathrm{p}}$ was determined using western blot in SNU-16 cells transfected by DN-AKT plasmid or control plasmid. The p-GSK $\beta$ was used as a control for AKT activity. (D) A western blot analysis of $\mathrm{H}_{2} \mathrm{~A}^{\mathrm{Y} 57 \mathrm{p}}$ in SNU-16 cells transfected with siRNA of AKT or siRNA control for $48 \mathrm{~h}$. (E) The level of H2A $\mathrm{A}^{\mathrm{Y} 57 \mathrm{p}}$ were measured by western blot assay in SNU-5 cells that were treated with LY294002 for 1 h, 6 h, and 12 h. AKT, protein kinase B; IGF, insulin-like growth factor; DN-AKT, dominant negative AKT; siRNA, small interfering RNA.

the same lysates were measured using western blot with a CK2 $\alpha$ antibody (Figure 2E). The results displayed in Figure $2 E$ also indicated that $\mathrm{p}-\mathrm{CK} 2 \alpha$ expression was blocked when AKT activity was inhibited by LY294002 or DNAKT. Additionally, after SNU-16 cells were transfected with mutant (MUT-) CK2 $\alpha$ plasmid (T13A-CK2 $\alpha$ plasmid, mimicking the unphosphorylated state) or treated with WT-CK2 $\alpha$ plasmid and LY294002, exogenous CK2 $\alpha$ levels were detected by immunoprecipitation and western blot assays. The results revealed that the expression of p-CK2 $\alpha$ could be blocked by LY294002 in SNU-16 cells transfected with $\mathrm{CK} 2 \alpha^{\mathrm{WT}}$, and its expression was also suppressed by CK2 $\alpha^{\mathrm{T} 13 \mathrm{~A}}$ plasmid (Figure $2 F$ ). Collectively, these findings supported that AKT interacts with CK2 $\alpha$ in cells, and AKT phosphorylated CK2 $\alpha$ at the T13 site.

\section{The AKT-mediated phosphorylation of CK2 $\alpha$ inhibits the phosphorylation of $\mathrm{H} 2 A^{Y 57}$}

We studied whether AKT-mediated phosphorylation of $\mathrm{CK} 2 \alpha$ could affect the phosphorylation of $\mathrm{H} 2 \mathrm{~A}^{\mathrm{Y} 57}$. Firstly, CA-AKT decreased the level of $\mathrm{H} 2 \mathrm{~A}^{\mathrm{Y} 57 \mathrm{p}}$, whereas DN-AKT increased the level of $\mathrm{H} 2 \mathrm{~A}^{\mathrm{Y} 57 \mathrm{p}}$ (Figure $3 A$ ). Thus, the activity of AKT was negatively correlated with the level of $\mathrm{H}_{2} \mathrm{~A}^{\mathrm{Y} 57}$ phosphorylation $\left(\mathrm{H}_{2} \mathrm{~A}^{\mathrm{Y} 57 \mathrm{p}}\right)$. Secondly, the level of $\mathrm{H} 2 \mathrm{~A}^{\mathrm{Y} 57 \mathrm{p}}$ in cells transfected with T13A-CK2 $\alpha$ was significantly higher than that in cells transfected with WT-CK2 $\alpha$ or T13E-CK2 $\alpha$ (mimicking the phosphorylated state) (Figure 3B). Hence, the level of p-CK2 $\alpha$ was negatively correlated with the level of $\mathrm{H} 2 \mathrm{~A}^{\mathrm{Y} 57 \mathrm{p}}$. Thirdly, the increase of $\mathrm{H} 2 \mathrm{~A}^{\mathrm{Y} 57 \mathrm{p}}$ expression caused by DN-AKT was reversed by knockdown of CK2 $\alpha$ (siRNA 


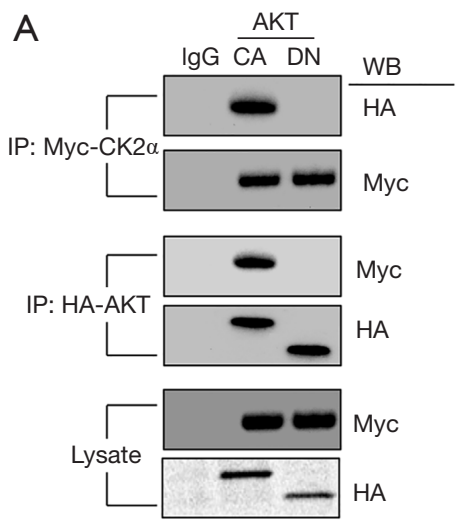

E

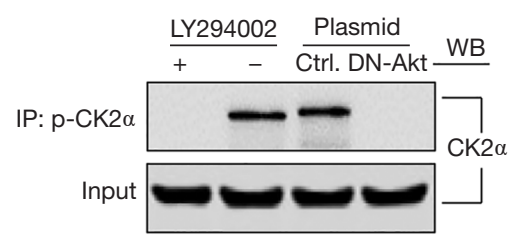

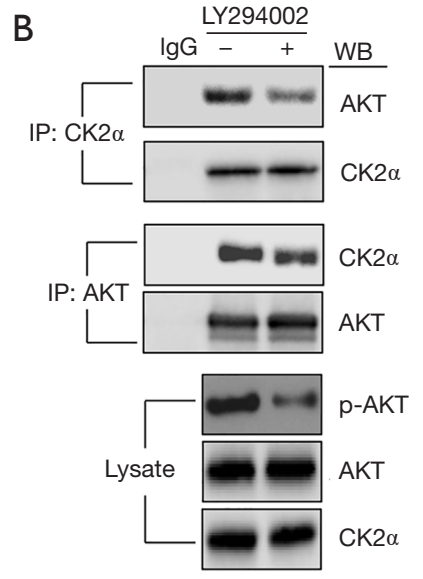
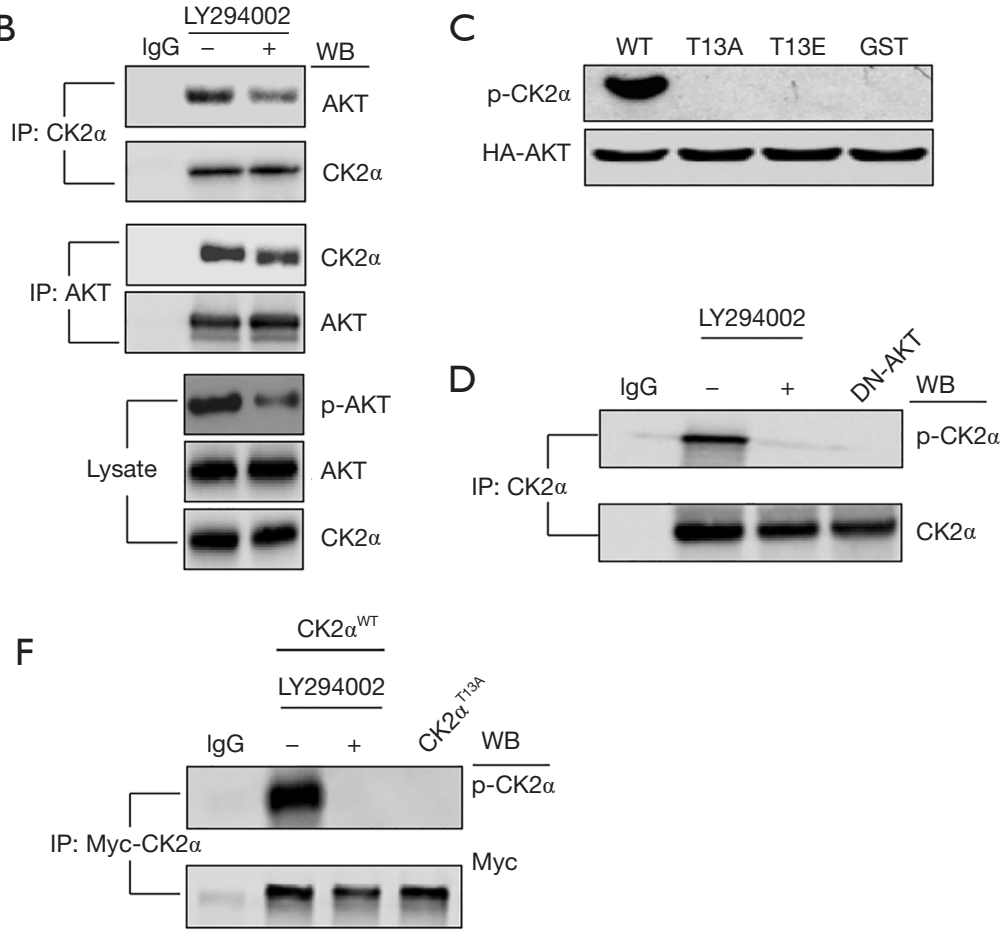

Figure 2 AKT phosphorylates CK2 $\alpha$ on T13 site. (A) Co-immunoprecipitation analysis of CK2 $\alpha$ and AKT. The lysates of SNU-16 cells transfected with the plasmids (CA-AKT or DN-AKT) were analyzed by immunoprecipitation with antibodies against HA or Myc. Meanwhile, western blot analysis was performed to detect the expression of CK2 $\alpha$ and AKT in whole cell lysates. The DN-AKT is a mutant that cannot be activated and can inhibit the activation of wild-type AKT in cells. The CA-AKT is a mutant with spontaneous and persistent activation. (B) The interaction between endogenous CK2 $\alpha$ and AKT in SNU-16 cells was detected by immunoprecipitation and western blot assays ( \pm LY294002). (C) HA-tagged AKT was expressed in SNU-16 cells and collected by immunoprecipitation. The interaction of HA-tagged AKT with WT-CK2 $\alpha$ and mutants of CK2 $\alpha$ (T13A, T13E, and GST) was measured by an in vitro kinase assay. (D) Endogenous CK2 afrom SNU-16 ( \pm LY294002) or DN-AKT/SNU-16 cells was analyzed by immunoprecipitation with an anti-CK2 $\alpha$ antibody, and then analyzed with western blot using an antibody against p-CK2 $\alpha$. (E) After SNU-16 cells were treated with LY294002 or DN-AKT, they were immunoprecipitated with a p-CK2 $\alpha$ antibody, and the same cell lysates were measured using western blot with a CK2 $\alpha$ antibody. (F) SNU16 cells were transfected with WT-CK2 $\alpha$ ( \pm LY294002) or T13A-CK2 $\alpha$, the exogenous CK2 $\alpha$ was determined by immunoprecipitation, and was subjected to western blot with an antibody against p-CK2 $\alpha$. AKT, protein kinase B; CA-AKT, constitutively activated-AKT; DN-AKT, dominant negative AKT; WT, wild-type.

CK2 $\alpha$, si-CK2 $\alpha$ ) (Figure 3C). Therefore, AKT-mediated phosphorylation of CK2 ainhibited the level of $\mathrm{H}_{2} \mathrm{~A}^{\mathrm{Y} 57 \mathrm{p}}$.

This result was further verified by in vitro the kinase activity assays. As shown in Figure 3D, AKT could not phosphorylate mutant CK2 $\alpha$ at the T13 site (CK2 $\alpha-\mathrm{T} 13 \mathrm{~A})$ and only phosphorylated WT-CK2 $\alpha$. In addition, the phosphorylation of CK2 $\alpha$ (p-CK2 $\alpha$ ) decreased the level of $\mathrm{H} 2 \mathrm{~A}^{\mathrm{Y} 57 \mathrm{p}}$. To further confirm this finding, a kinase activity assay was performed on WT-, T13A, or T13E-CK2 $\alpha$, and $\mathrm{H} 2 \mathrm{~A}$ expressed in vitro. The unphosphorylated state of CK2 $\alpha$ (T13A-CK2 $\alpha$ ) and its normal state (WT-CK2 $\alpha$ ) could enhance the level of $\mathrm{H} 2 \mathrm{~A}^{\mathrm{Y} 5 \mathrm{p}}$ as compared to the control group, but the phosphorylated state of CK2 $\alpha$ (T13E-CK2 $\alpha)$ decreased the level of $\mathrm{H}_{2} \mathrm{~A}^{\mathrm{Y} 57 \mathrm{p}}$ compared with the WTCK2 $\alpha$ and T13A-CK2 $\alpha$ groups (Figure 3E). Therefore, the above experimental data indicated that AKT-mediated phosphorylation of CK2 $\alpha$ can inhibit the level of $\mathrm{H} 2 \mathrm{~A}^{\mathrm{Y} 57 \mathrm{p}}$.

\section{AKT-mediated phosphorylation of CK $2 \alpha$ changes substrate affinity}

To test whether AKT-mediated phosphorylation changed the affinity of $\mathrm{CK} 2 \alpha$ with its substrate histone $\mathrm{H} 2 \mathrm{~A}$, a CoIP assay was performed to determine the combination 
A

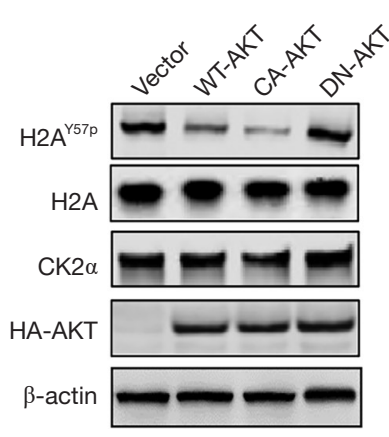

D

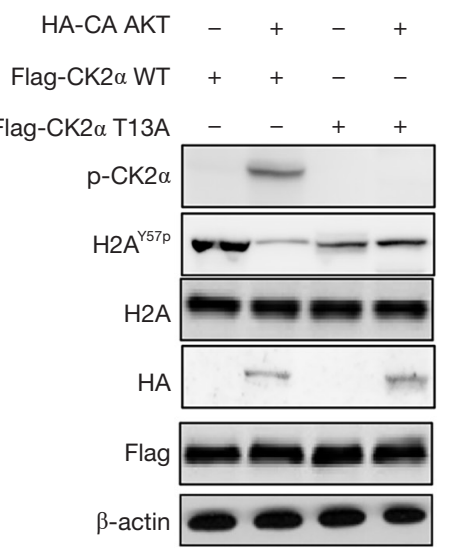

B

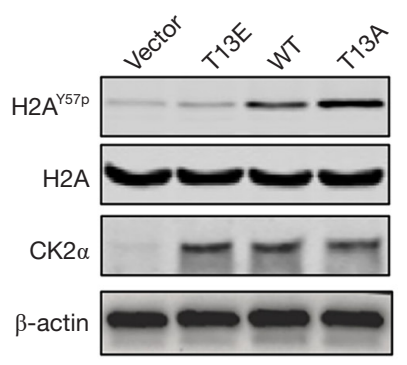

$E$

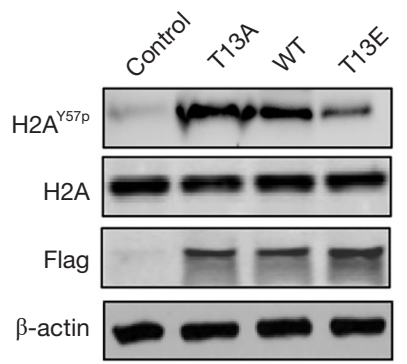

C

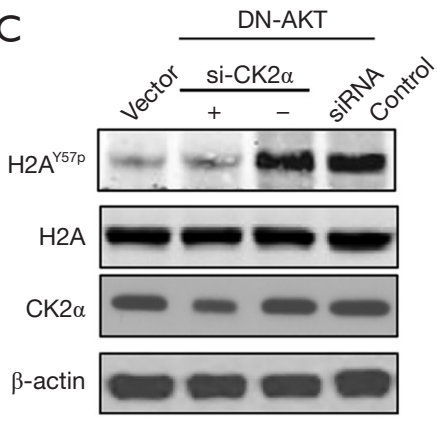

Figure 3 The AKT-mediated phosphorylation of CK2 $\alpha$ inhibits the phosphorylation of $\mathrm{H}_{2} \mathrm{~A}^{\mathrm{Y57}}$. (A) SNU-16 cells were co-transfected with CK2 $\alpha$ and WT-AKT, CA-AKT or DN-AKT plasmids. Samples were collected after $48 \mathrm{~h}$ of transfection and analyzed by western blot. (B) SNU-16 cells were transfected with WT- or MUT-CK2 $\alpha$ (T13A, T13E). Samples were collected after $48 \mathrm{~h}$ of transfection and analyzed by western blot. (C) DN-AKT/SNU-16 cells were transfected by control (ctrl) or siRNA CK2 $\alpha$. Samples were collected after $48 \mathrm{~h}$ of transfection and analyzed by western blot. (D) HA-CA-AKT immunoprecipitated from unstimulated cell lysates was mixed with FLAGtagged WT-CK2 $\alpha$ or the T13A mutant and then analyzed by performing a kinase activity assay. (E) FLAG-tagged WT-CK2 $\alpha$, T13E, or T13A mutant were expressed in vitro and immunopurified with an anti-FLAG antibody. Kinase activity was then assayed. AKT, protein kinase B; CA-AKT, constitutively activated-AKT; DN-AKT, dominant negative AKT; WT, wild-type; siRNA, small interfering RNA.

of histone $\mathrm{H} 2 \mathrm{~A}$ with CK2 $\alpha$. The experimental results suggested that T13A-CK2 $\alpha$ showed a greater correlation with $\mathrm{H} 2 \mathrm{~A}$ as compared to WT- or T13E-CK2 $\alpha$, but the correlation between WT-CK2 $\alpha$ with $\mathrm{H} 2 \mathrm{~A}$ was enhanced after LY294002 treatment (Figure 4A). Additionally, insoluble (chromatin-bound, c) and soluble (s) nuclear fractions were isolated from SNU-16 cells treated with LY294002, DN-AKT, or IGF. Reduced AKT activity caused by LY294002 or DN-AKT increased the amount of chromatin-bound CK2 $\alpha$ but decreased the level of soluble CK2 $\alpha$ (Figure 4B). Furthermore, activation of AKT induced by IGF decreased chromatin-bound CK2 $\alpha$ but increased soluble CK2 $\alpha$, whereas this situation was reversed by the introduction of LY294002 (Figure 4C). Therefore, AKTmediated CK2 $\alpha$ phosphorylation reduced the affinity of
CK2 $\alpha$ with its substrate histone H2A, which resulted in a decrease of $\mathrm{H} 2 \mathrm{~A}^{\mathrm{Y} 57 \mathrm{p}}$ level.

\section{Downregulated of $\mathrm{H} 2 A^{Y 577}$ induced by AKT-mediated CK2 $\alpha$ phosphorylation promotes cell proliferation, migration, and invasion}

To validate whether downregulation of $\mathrm{H} 2 \mathrm{~A}^{\mathrm{Y} 57 \mathrm{p}}$ induced by AKT-mediated p-CK2 $\alpha$ can affect the growth of GC cells, we performed CCK-8, wound healing, transwell invasion assays and apoptosis assays on the transfected SNU-16 cells. Firstly, after SNU-16 cells were transfected with control vectors, CA-AKT, CA-AKT+T13A-CK2 $\alpha, \mathrm{DN}-\mathrm{AKT}$, and $\mathrm{DN}-\mathrm{AKT}+\mathrm{T} 13 \mathrm{E}-\mathrm{CK} 2 \alpha$, the protein expression of $\mathrm{H} 2 \mathrm{~A}^{\mathrm{Y} 57 \mathrm{p}}$ was determined by western blot (Figure $5 A$ ). The level of 
A

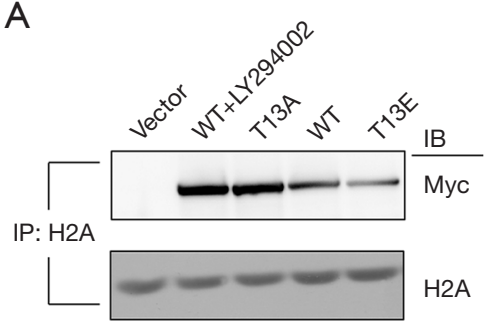

B

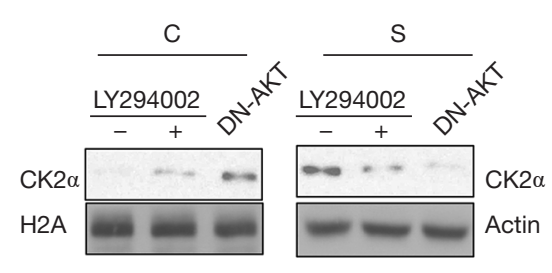

C

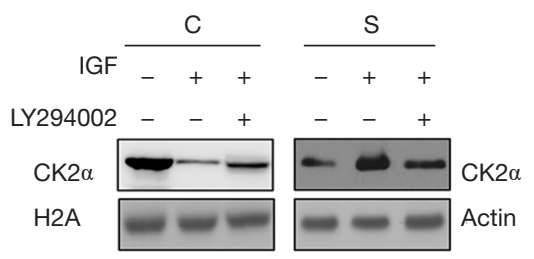

Figure 4 AKT-mediated phosphorylation of CK2 $\alpha$ changes substrate affinity. (A) Co-immunoprecipitation of endogenous histone H2A and WT- or MUT-CK2 $\alpha$ (T13A, T13E) from SNU-16 cells. (B,C) The endogenous CK2 $\alpha$ in soluble (s) and chromatin-bound (c) was analyzed by western blotting, with constituents fractions used in western blot from SNU-16 ( \pm LY294002) and DN-AKT/SNU-16 cells (B) or from SNU-16 cells (C) treated with IGF or processed successively by IGF and LY294002. AKT, protein kinase B; DN-AKT, dominant negative AKT; WT, wild-type; IGF, insulin-like growth factor.

$\mathrm{H} 2 \mathrm{~A}^{\mathrm{Y} 57 \mathrm{p}}$ was decreased by the activation of AKT (CA-AKT transfection) compared with the control group and yet this situation was changed by the co-transfection of CAAKT with T13A-CK2 $\alpha$ (Figure 5A). Besides, the increase of $\mathrm{H}_{2} \mathrm{~A}^{\mathrm{Y} 57 \mathrm{p}}$ level caused by the inhibition of AKT activity (DN-AKT transfection) was reversed by the introduction of T13E-CK2 $\alpha$ (Figure 5A). Secondly, the CCK- 8 assay indicated that the promotion of SNU-16 cell proliferation induced by CA-AKT was suppressed by the introduction of T13A-CK2 $\alpha$, and the inhibition of the cell proliferation caused by DN-AKT was improved after SNU-16 cells were co-transfected with DN-AKT and T13E-CK2 $\alpha$ (Figure $5 B$ ). Thirdly, wound healing and transwell invasion assays showed that CA-AKT obviously promoted the migration and invasion of SNU-16 cells in comparison to the control group but the introduction of T13A-CK $2 \alpha$ suppressed the increase tendency (Figure $5 C, 5 D$ ). In addition, the inhibition of the cell migration and invasion caused by DN-AKT was improved by T13E-CK $2 \alpha$ co-transfected with DN-AKT into SNU-16 cells (Figure 5C,5D). Finally, the results of apoptosis assay indicated that CA-AKT and T13E-CK2 $\alpha$ decreased the apoptosis rate, while DN-AKT and T13A-CK2 $\alpha$ increased it (Figure 5E). Therefore, the change of $\mathrm{H}_{2} \mathrm{~A}^{\mathrm{Y} 57 \mathrm{p}}$ level was associated with the growth and metastasis of SNU-16 cells, and consequently we speculated that AKT-mediated CK $2 \alpha$ phosphorylation promoted the proliferation, migration, invasion and inhibited the apoptosis of SNU-16 cells possibly through downregulating $\mathrm{H} 2 \mathrm{~A}^{\mathrm{Y} 57 \mathrm{p}}$ level.

\section{Discussion}

Our study indicated that AKT-mediated phosphorylation of CK2 $\alpha$ at the T13 site inhibited the phosphorylation level of histone $\mathrm{H} 2 \mathrm{~A}$ at the Y57 site in GC cells. Besides, the enhanced phosphorylation of CK2 $\alpha$ decreased the affinity of CK2 $\alpha$ with its substrate histone $\mathrm{H} 2 \mathrm{~A}$, resulting in a decreased $\mathrm{H} 2 \mathrm{~A}^{\mathrm{Y} 57 \mathrm{p}}$ level. Furthermore, AKT-mediated CK $2 \alpha$ phosphorylation promoted the proliferation, migration, and invasion of SNU-16 cells possibly through downregulating the $\mathrm{H} 2 \mathrm{~A}^{\mathrm{Y} 57 \mathrm{p}}$ level.

Serine/threonine kinase AKT is one of the main downstream targets of the phosphatidylinositol 3 kinase (PI3K) pathway (22), which mediates a series of survival promoting signals, such as proliferation, anti-apoptosis, angiogenesis, and cell growth (23). The abnormal activation of AKT is related to the occurrence of a variety of diseases and the chemoresistance of tumors $(22,24)$. Furthermore, AKT also participates in histone modifications to mediate the progression and development of cancers $(15,16)$. The Ras-AKT signaling pathway promotes the progression of glioma through inhibiting the phosphorylation of histone H1.5 (17). It has been shown that AKT can control H3K4 methylation to modulate the breast cancer epigenome (25). Thus, the interaction between AKT and histone modifications in cancers has attracted increasing attention.

Histones are mainly composed of 4 kinds of core histone including $\mathrm{H} 2 \mathrm{~A}, \mathrm{H} 2 \mathrm{~B}, \mathrm{H} 3$, and $\mathrm{H} 4$, which play an important regulatory role in the genome (26). It has been reported that the post-translational modification mechanism of histone $\mathrm{H} 2 \mathrm{~A}$ and its variants has a certain impact on DNA damage repair and the occurrence and development of cancer. For instance, the ubiquitination mechanism of H2A inhibits transcription activity and DNA damage repair activity, thus increasing the incidence of breast and ovarian cancers (27). The high expression of histone variant H2A. 
A

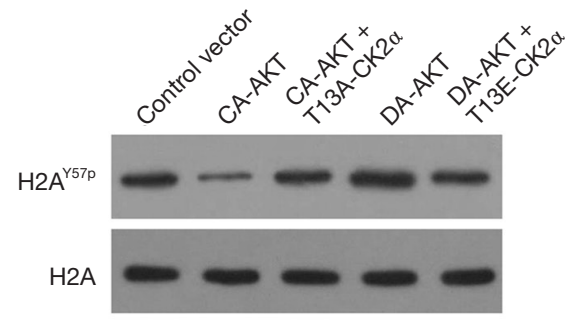

Control vector

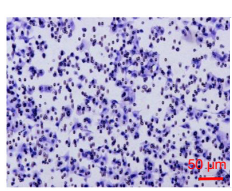

Control vector
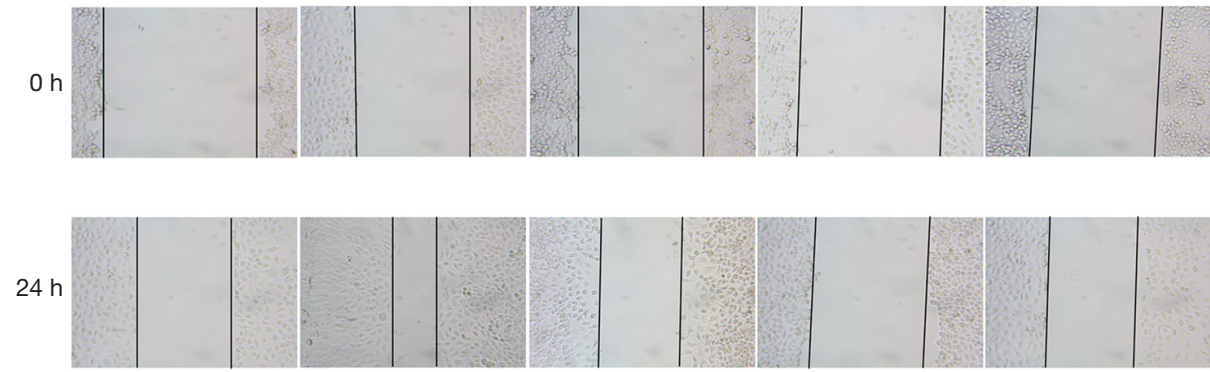

$\mathrm{E}$

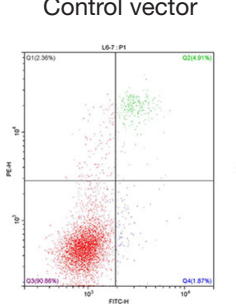

CA-AKT $\quad$ CA-AKT + T13A-CK $2 \alpha$
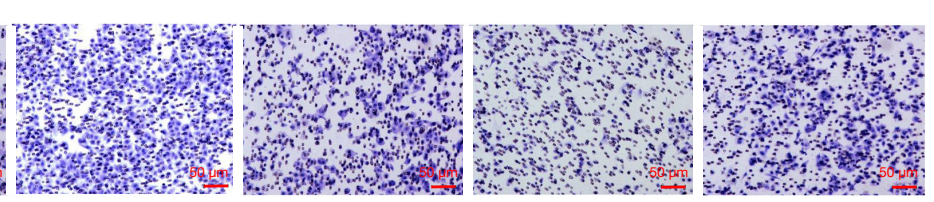

$=$ CA-AKT

- CA-AKT + T13A-CK2

$\rightarrow$ DN-AKT

$\rightarrow$ DN-AKT + T13E-CK2 $\alpha$
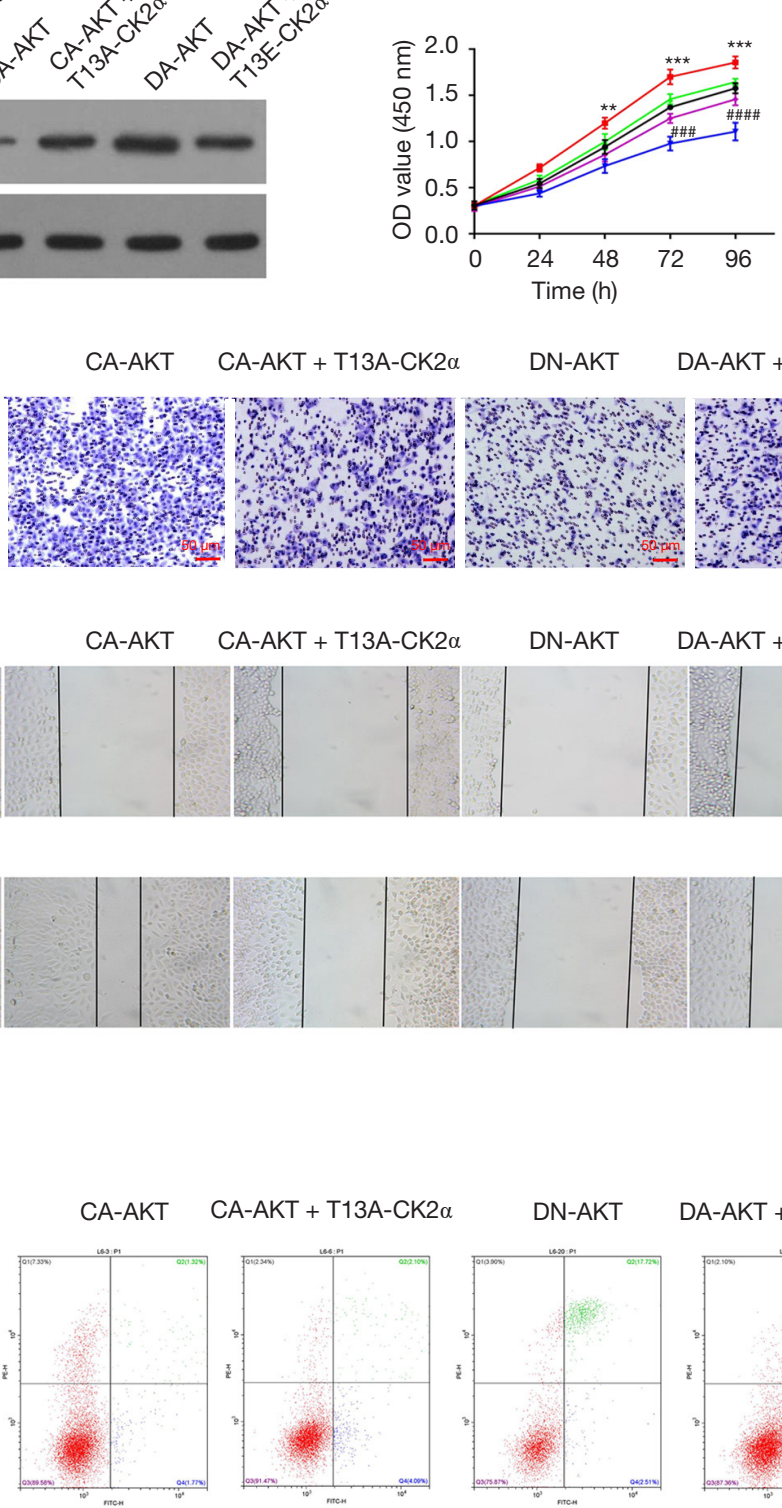

DN-AKT

DA-AKT + T13E-CK2 $\alpha$
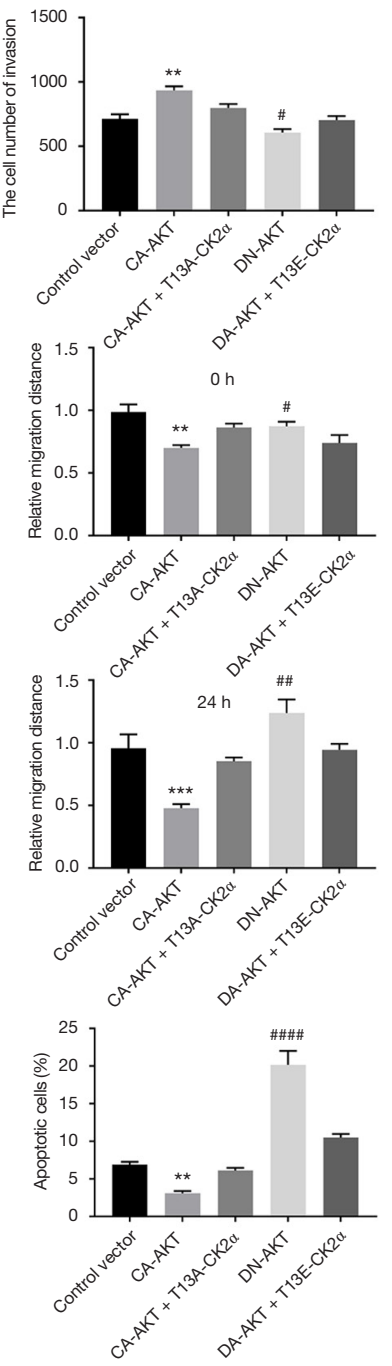

Figure 5 Downregulated of $\mathrm{H}_{2} \mathrm{~A}^{\mathrm{Y57 \textrm {p }}}$ induced by AKT-mediated CK2 $\alpha$ phosphorylation promotes cell proliferation, migration and invasion. After SNU-16 cells were transfected with a control vector, CA-AKT, CA-AKT+T13A-CK2 $\alpha$, DN-AKT, DN-AKT+T13E-CK2 $\alpha$, (A) the protein expression of $\mathrm{H}_{2} \mathrm{~A}^{\mathrm{Y} 57 \mathrm{p}}$ was determined by western blot; (B) the proliferation of SNU-16 cells was detected using CCK-8 assay; (C) the cellular invasion was measured with transwell invasion assay (Crystal Violet Staining, scale $50 \mu \mathrm{m}$ ); (D) the cellular migration was assessed using wound healing assay. (E) the apoptotic rate was detected by flow cytometry. ${ }^{*}, \mathrm{P}<0.01,{ }^{* * *}, \mathrm{P}<0.001$ vs. CA-AKT+T13ACK2 $\alpha$ group; ${ }^{\prime}, \mathrm{P}<0.05,{ }^{\prime \prime \prime}, \mathrm{P}<0.01,{ }^{\text {\#\#\#, }, \mathrm{P}<0.001,{ }^{\prime \prime \prime \prime \prime \prime \prime ~}}, \mathrm{P}<0.0001$ vs. DN-AKT+T13E-CK2 $\alpha$. AKT, protein kinase B; CA-AKT, constitutively activated-AKT; DN-AKT, dominant negative AKT; CCK-8, Cell Counting Kit-8.

$\mathrm{Z}$ in breast cancer and its antagonism to DNA methylation may lead to gene silencing, including the silence of tumor suppressor genes (28). The phosphorylation level of histone variant H2A.X can regulate the progress of cancer, and can also serve as a biomarker of cancer prognosis and treatment evaluation (29). The site $\mathrm{H} 2 \mathrm{~A}$ at $\operatorname{Tyr} 57\left(\mathrm{H}_{2} \mathrm{~A}^{\mathrm{Y} 57}\right)$, a new 
conserved phosphorylation site in $\mathrm{H} 2 \mathrm{~A}$, is able to mediate transcriptional elongation via CK2 $\alpha$ regulation (14). To date, there are few reports regarding the interaction of $\mathrm{H} 2 \mathrm{~A}$ with AKT. To explore this issue, our study first found that AKT was negatively correlated with the phosphorylation level of $\mathrm{H} 2 \mathrm{~A}$ at Tyr57 site $\left(\mathrm{H} 2 \mathrm{~A}^{\mathrm{Y} 57}\right)$ in GC cells.

We further explored the detailed mechanism between $\mathrm{H} 2 \mathrm{~A}^{\mathrm{Y} 57}$ and AKT. On one hand, the phosphorylation of the $\mathrm{H} 2 \mathrm{~A}$ at $\mathrm{Y} 57$ site is mediated by CK2 $\alpha(14,30)$. On the other hand, the aberrant expression of CK2 $\alpha$ is also correlated to tumor; for instance, Wu et al. found that CK2 $\alpha$ knockout can inhibit the migration and invasion of liver cancer cells (31); Liu et al. found that CK2 $\alpha$ levels in non-small cell lung cancer cells increased abnormally (32), and Zhang et al. showed that over expression of CK2 $\alpha$ promotes the development of human malignant pleural mesothelioma (33). Hence, we speculated that AKT might interact with $\mathrm{CK} 2 \alpha$ to regulate $\mathrm{H} 2 \mathrm{~A}^{\mathrm{Y} 57}$ phosphorylation, and their interaction could be involved in the progression of GC. In order to confirm this hypothesis, we carried out CoIP and western blotting experiments, and the results showed that AKT inhibited the phosphorylation of $\mathrm{H} 2 \mathrm{~A}^{\mathrm{Y} 57}$ by phosphorylating CK2 $\alpha$. In addition, enhanced phosphorylation of CK2 $\alpha$ decreased the affinity of CK2 $\alpha$ with its substrate histone $\mathrm{H} 2 \mathrm{~A}$, leading to a decrease of H2 $\mathrm{A}^{\mathrm{Y} 57 \mathrm{p}}$ level. Moreover, AKT-mediated CK $2 \alpha$ phosphorylation promoted the proliferation, migration, and invasion of GC cells possibly through downregulating $\mathrm{H} 2 \mathrm{~A}^{\mathrm{Y} 57 \mathrm{p}}$ level.

\section{Conclusions}

In conclusion, AKT can phosphorylate CK2 $\alpha$ at the T13 site, which decreases the affinity of CK2 $\alpha$ with its substrate histone $\mathrm{H} 2 \mathrm{~A}$ and inhibits the phosphorylation of $\mathrm{H}_{2} \mathrm{~A}^{\mathrm{Y} 57}$. Moreover, the interaction among AKT, CK2 $\alpha$, and $\mathrm{H} 2 \mathrm{~A}$ affected the proliferation, migration, and invasion of GC cells. Therefore, these molecules are effective biological targets for the treatment of GC, and provide new ideas for understanding the pathogenesis of GC.

\section{Acknowledgments}

Funding: This work was supported by grants from the National Nature Science Foundation of China (81972790, 81672319, 81602507, 81773135, and 81572465).

\section{Footnote}

Reporting Checklist: The authors have completed the
MDAR reporting checklist. Available at https://dx.doi. org/10.21037/jgo-21-260

Data Sharing Statement: Available at https://dx.doi. org/10.21037/jgo-21-260

Conflicts of Interest: All authors have completed the ICMJE uniform disclosure form (available at https://dx.doi. org/10.21037/jgo-21-260). Dr. LC reported that this work was supported by grants from the National Nature Science Foundation of China (81972790, 81672319, 81602507, 81773135 , and 81572465$)$. The other authors have no conflicts of interest to declare.

Ethical Statement: The authors are accountable for all aspects of the work in ensuring that questions related to the accuracy or integrity of any part of the work are appropriately investigated and resolved. The study was conducted in accordance with the Declaration of Helsinki (as revised in 2013). Institutional ethical approval and informed consent were waived.

Open Access Statement: This is an Open Access article distributed in accordance with the Creative Commons Attribution-NonCommercial-NoDerivs 4.0 International License (CC BY-NC-ND 4.0), which permits the noncommercial replication and distribution of the article with the strict proviso that no changes or edits are made and the original work is properly cited (including links to both the formal publication through the relevant DOI and the license). See: https://creativecommons.org/licenses/by-nc-nd/4.0/.

\section{References}

1. Kamangar F, Dores GM, Anderson WF. Patterns of cancer incidence, mortality, and prevalence across five continents: defining priorities to reduce cancer disparities in different geographic regions of the world. J Clin Oncol 2006;24:2137-50.

2. Zhou Q, Wu X, Wang X, et al. The reciprocal interaction between tumor cells and activated fibroblasts mediated by TNFalpha/IL-33/ST2L signaling promotes gastric cancer metastasis. The reciprocal interaction between tumor cells and activated fibroblasts mediated by TNF- $\alpha / \mathrm{IL}-33 / \mathrm{ST} 2 \mathrm{~L}$ signaling promotes gastric cancer metastasis. Oncogene 2020;39:1414-28.

3. Sakuramoto S, Sasako M, Yamaguchi T, et al. Adjuvant chemotherapy for gastric cancer with S-1, an oral fluoropyrimidine. N Engl J Med 2007;357:1810-20.

4. Bang YJ, Kim YW, Yang HK, et al. Adjuvant capecitabine and oxaliplatin for gastric cancer after D2 gastrectomy (CLASSIC): a phase 3 open-label, randomised controlled trial. Lancet 
2012;379:315-21.

5. Tsujimoto H, Ono S, Ichikura T, et al. Roles of inflammatory cytokines in the progression of gastric cancer: friends or foes? Gastric Cancer 2010;13:212-21.

6. Chia NY, Tan P. Molecular classification of gastric cancer. Ann Oncol 2016;27:763-9.

7. Waddington CH. The epigenotype. 1942. Int J Epidemiol 2012;41:10-3.

8. Tsou PS, Sawalha AH. Unfolding the pathogenesis of scleroderma through genomics and epigenomics. J Autoimmun 2017;83:73-94.

9. Handy DE, Castro R, Loscalzo J. Epigenetic modifications: basic mechanisms and role in cardiovascular disease. Circulation 2011;123:2145-56.

10. Stillman B. Histone Modifications: Insights into Their Influence on Gene Expression. Cell 2018;175:6-9.

11. Jbara M, Maity SK, Morgan M, et al. Chemical Synthesis of Phosphorylated Histone H2A at Tyr57 Reveals Insight into the Inhibition Mode of the SAGA Deubiquitinating Module. Angew Chem Int Ed Engl 2016;55:4972-6.

12. Sharma A, Singh K, Almasan A. Histone H2AX phosphorylation: a marker for DNA damage. Methods Mol Biol 2012;920:613-26.

13. Kawashima SA, Yamagishi Y, Honda T, et al. Phosphorylation of H2A by Bub1 prevents chromosomal instability through localizing shugoshin. Science 2010;327:172-7.

14. Basnet H, Su XB, Tan Y, et al. Tyrosine phosphorylation of histone $\mathrm{H} 2 \mathrm{~A}$ by $\mathrm{CK} 2$ regulates transcriptional elongation. Nature 2014;516:267-71.

15. LeeJV, Carrer A, Shah S, et al. Akt-dependent metabolic reprogramming regulates tumor cell histone acetylation. Cell Metab 2014;20:306-19.

16. Cha TL, Zhou BP, Xia W, et al. Akt-mediated phosphorylation of EZH2 suppresses methylation of lysine 27 in histone $\mathrm{H} 3$. Science 2005;310:306-10.

17. Sang B, Sun J, Yang D, et al. Ras-AKT signaling represses the phosphorylation of histone $\mathrm{H} 1.5$ at threonine 10 via GSK3 to promote the progression of glioma. Artif Cells Nanomed Biotechnol 2019;47:2882-90.

18. Park JH, Kim CK, Lee SB, et al. Akt attenuates apoptotic death through phosphorylation of $\mathrm{H} 2 \mathrm{~A}$ under hydrogen peroxideinduced oxidative stress in PC12 cells and hippocampal neurons. Sci Rep 2016;6:21857.

19. Dong $\mathrm{C}$, Sun J, Ma S, et al. K-ras-ERK1/2 down-regulates H2A.X (Y142ph) through WSTF to promote the progress of gastric cancer. BMC Cancer 2019;19:530.

20. Yang WY, Gu JL, Zhen TM. Recent advances of histone modification in gastric cancer. J Cancer Res Ther 2014;10 Suppl:240-5.

21. Singh SS, Yap WN, Arfuso F, et al. Targeting the PI3K/Akt signaling pathway in gastric carcinoma: A reality for personalized medicine? World J Gastroenterol 2015;21:12261-73.

22. Manning BD, Toker A. AKT/PKB Signaling: Navigating the Network. Cell 2017;169:381-405.

23. Hasselblom S, Hansson U, Olsson M, et al. High immunohistochemical expression of p-AKT predicts inferior survival in patients with diffuse large B-cell lymphoma treated with immunochemotherapy. Br J Haematol 2010;149:560-8.

24. Manning BD, Cantley LC. AKT/PKB signaling: navigating downstream. Cell 2007;129:1261-74.

25. Spangle JM, Dreijerink KM, Groner AC, et al. PI3K/AKT Signaling Regulates H3K4 Methylation in Breast Cancer. Cell Rep 2016;15:2692-704.

26. Conerly ML, Teves SS, Diolaiti D, et al. Changes in H2A.Z occupancy and DNA methylation during B-cell lymphomagenesis. Genome Res 2010;20:1383-90.

27. Stewart MD, Zelin E, Dhall A, et al. BARD1 is necessary for ubiquitylation of nucleosomal histone $\mathrm{H} 2 \mathrm{~A}$ and for transcriptional regulation of estrogen metabolism genes. Proc Natl Acad Sci U S A 2018;115:1316-21.

28. Hua S, Kallen CB, Dhar R, et al. Genomic analysis of estrogen cascade reveals histone variant $\mathrm{H} 2 \mathrm{~A} . \mathrm{Z}$ associated with breast cancer progression. Mol Syst Biol 2008;4:188.

29. Corujo D, Buschbeck M. Post-Translational Modifications of H2A Histone Variants and Their Role in Cancer. Cancers (Basel) 2018;10:59.

30. Sueoka T, Hayashi G, Okamoto A. Regulation of the Stability of the Histone H2A-H2B Dimer by H2A Tyr57 Phosphorylation. Biochemistry 2017;56:4767-72.

31. Wu D, Sui C, Meng F, et al. Stable knockdown of protein kinase CK2-alpha (CK2alpha) inhibits migration and invasion and induces inactivation of hedgehog signaling pathway in hepatocellular carcinoma Hep G2 cells. Acta Histochem 2014;116:1501-8.

32. Liu Y, Amin EB, Mayo MW, et al. CK2alpha' Drives Lung Cancer Metastasis by Targeting BRMS1 Nuclear Export and Degradation. Cancer Res 2016;76:2675-86.

33. Zhang S, Yang YL, Wang Y, et al. CK2alpha, over-expressed in human malignant pleural mesothelioma, regulates the Hedgehog signaling pathway in mesothelioma cells. J Exp Clin Cancer Res 2014;33:93.

(English Language Editor: J. Jones)

Cite this article as: Chen ZD, Zhang PF, Xi HQ, Wei B, Chen L. AKT inhibits the phosphorylation level of H2A at Tyr57 via CK2 $\alpha$ to promote the progression of gastric cancer. J Gastrointest Oncol 2021;12(4):1363-1373. doi: 10.21037/jgo$21-260$ 


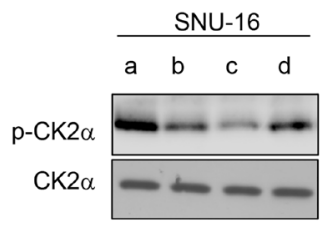

Figure S1 Specificity of the anti-p-CK2 $\alpha$ antibody. (a, b) The levels of phospho-CK2 $\alpha$ from SNU-16 cells transfected with DN-AKT plasmid or scramble plasmid (control) were determined using western blot. (c, d) The levels of phospho-CK2 $\alpha$ from SNU-16 cells were detected by western blot. The antibody was introduced using peptide competition processes, among which the antibody against p-CK2 $\alpha$ was pre-incubated with phospho-CK2 $\alpha$ or non-phospho-CK2 $\alpha$ peptides. a: control, b: DN-AKT transfection; c: the p-CK2 $\alpha$ antibody was preincubated with phospho-CK2 $\alpha$; d: the p-CK2 $\alpha$ antibody was pre-incubated with non-phospho-CK2 $\alpha$ peptides. AKT, protein kinase B; CAAKT, constitutively activated-AKT; DN-AKT, dominant negative AKT. 